\title{
Securitizing Borders: The Case of South Tyrol
}

\author{
Andrea Carlà* \\ Eurac Research - Institute for Minority Rights, Bolzano/Bozen, Italy \\ ${ }^{\star}$ Corresponding author. Email: andrea.carla@eurac.edu
}

\begin{abstract}
Situated at the interplay between ethnic politics, migration, border, and security studies, this contribution analyzes processes of securitization of borders in South Tyrol, an Italian province bordering Austria and Switzerland with a German- and Ladin-speaking population and a past of ethnic tensions. South Tyrol is considered a model for fostering peaceful interethnic relations thanks to a complex power-sharing system. However, the arrival of migrants from foreign countries and the more recent influx of asylum seekers have revitalized debates around the borders between South Tyrol/Italy and Austria and among South Tyrolean linguistic groups. The current COVID-19 pandemic has brought further complexity to the issue. I use the concept of securitization - the process through which an issue is considered as an existential threat requiring exceptional measures - in order to understand why and how borders become exclusionary and restrictive, shaping dynamics of othering. With this framework, the article explores how South Tyrolean borders have been subjected to (de)securitizing and resecuritizing moves in discourses and practices. In this way, I shed new light on debates on the articulation of borders and interethnic relations that are occurring due to recent international migration, consolidation of nationalist agendas, and the current pandemic.
\end{abstract}

Keywords: borders; securitization; South Tyrol; migration; interethnic relations

\section{Introduction}

Even as we celebrated the 30th anniversary of the fall of the Berlin Wall, one of the most notorious borders in recent human history, the subject of borders has never been so present and relevant. In recent years, due to large-scale movements of migrants and asylum seekers, many nationalist and populist politicians around the world have invoked in words and deeds the need to build walls, close frontiers, and block harbors. This rearticulation of borders is intended to protect their respective nations from undesirable others.

In this regard, the Brenner border between Italy and Austria, and its borderland South Tyrol, epitomizes this shifting and multifaceted perspective on borders along with the challenges and quandaries around the notion of a border. Established after World War I, the Brenner border signaled the annexation by the Italian state of the German-speaking province of South Tyrol, historically a site of controversy and contestation that resulted in ethnic tensions in the 1950s and 1960s. Thanks to a consociational "complex power-sharing system," most of these tensions have vanished, and South Tyrol is today considered a model for dealing with ethnic conflicts (Wolff 2008). Thus, the Brenner border has lost its political weight, and relations between South Tyrolean Italian and German speakers are peaceful. However, the arrival of numerous foreign migrants since the mid-1990s and the more recent influx of asylum seekers, who cross South Tyrol in their attempt to reach northern Europe, have revitalized debates around the Brenner border and the boundaries

(C) The Author(s), 2021. Published by Cambridge University Press on behalf of Association for the Study of Nationalities. This is an Open Access article, distributed under the terms of the Creative Commons Attribution licence (http://creativecommons.org/licenses/by/4.0/), which permits unrestricted re-use, distribution, and reproduction in any medium, provided the original work is properly cited. 
between South Tyrolean ethnic-linguistic groups. Embedded in nationalist and populist claims, identity concerns and new us-versus-them dichotomies have arisen. Furthermore, when, at the beginning of 2020, Italy became the first European country where the coronavirus was spreading rapidly, the Austrian government closed its borders to most Italian citizens.

Situated at the interplay between the fields of ethnic politics, migration, border studies, and security studies, this article aims to refract the South Tyrol case through the notion of border(s). I adopt the concept of securitization as my analytical framework. Securitization refers to the process through which an issue is considered an existential threat requiring exceptional measures (Buzan, Wæver, and de Wilde 1998). I use securitization alongside its inverse process of desecuritization, understood as the unmaking of securitization and the removing of a certain issue from the security mode (Huysmans 2006). I apply this concept to explore developments surrounding political, administrative, and cultural-linguistic borders. I argue that tracing processes of securitization furthers our understanding of why and how borders acquire a negative connotation, in the sense that they are constructed in exclusionary and conflictual terms, shaping dynamics of othering. In contrast, desecuritization can be understood as a process that frames borders more positively as places of encounter and exchange.

With this framework, the article examines discourses and practices related to South Tyrolean political, administrative, and cultural borders. It traces how South Tyrolean borders experienced (de)securitizing and resecuritizing moves, by which they have been constructed and deconstructed either as loci of exclusion and tensions or in more positive terms. I show that South Tyrolean borders have previously experienced desecuritization dynamics, thereby they were seen in a positive light in regard to past ethnic tensions and interethnic relations. However, more recently, in light of current migratory flows and then the arrival of asylum seekers, we can detect a process of resecuritization of South Tyrolean borders, with consequences for South Tyrolean ethnic politics; this development has been further reinforced during the COVID-19 pandemic.

In this way, I contribute new insights to the debate on the articulation of borders and interethnic relations against the backdrop of recent international migration, consolidation of nationalist agendas, and the current pandemic. The article builds on and contributes to three types of literatures, fostering interactions and dialogue among their disciplinary fields. First, it enriches existing scholarship on South Tyrol. Many works on the province have mainly provided historic or legal accounts, and to a lesser extent they have examined South Tyrol from the perspective of conflict settlement theory and ethnic parties or the interplay between consociational institutions and intergroup relations (Grote 2012; Woelk, Palermo, and Marko 2008; Scantamburlo 2016). In contrast, I stress the relevance of (de)securitizing dynamics affecting the various South Tyrolean borders as they relate to the ethnic politics and relations in the province. Second, a growing number of studies have applied securitization to minority issues. However, such work tends to focus on how minorities and specific communities are perceived as a threat, become target of illiberal policies, and/or cause ethnic tensions (Olesker 2014; van Willigen 2010). By focusing on borders, I highlight the boundary-making dynamic that is inherent in securitization processes and its effect on majority-minority relations. Finally, the article is linked to research on the interplay between minority and migration issues, where scholars in particular working on South Tyrol have pointed out that the ethnic features and consociational mechanisms of the province have fostered negative attitudes toward migration (Wisthaler 2016). Inverting the perspective, the article shows instead how migration affects the understanding of the boundaries of South Tyrol and among its linguistic groups. Overall, the article represents an attempt at cross-fertilization among different research disciplines as an answer to calls for deeper interdisciplinarity across fields.

The article is structured in three parts. First, after theoretically discussing the notion of borders and sketching a brief history of South Tyrolean borders, I present my (de)securitization framework of analysis and provide a brief methodological note. The second and third sections apply this framework to the South Tyrol case, focusing on three distinct aspects. I focus on South Tyrolean borders in light of the complex institutional mechanisms put in place to deal with the past ethnic 
tensions. Then I consider how demographic transformations due to current migratory flows and the more recent arrival of asylum seekers intersect with South Tyrolean ethnic issues and South Tyrolean borders. Finally, I explore developments linked to the current pandemic.

\section{What Is a Border?}

Human society is characterized by the presence of numerous borders; people cross borders constantly, at times even without realizing it or paying attention. However, what actually constitutes a border? In the English language, the word border refers to "the line that divides one country or place from another" and "a strip that goes around or along the edge of something, or the edge

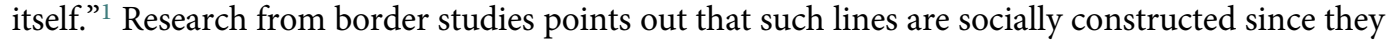
are not, as on political maps, drawn in nature. They do not actually materially exist and are invisible per se. To be sure, at times, borders can coincide with specific elements and geographical features; however, these elements are not borders in themselves but rather are made into borders through performative discourses and practices (Wlasak 2017). If, a nation-state is an "imagined community" (Anderson 1983), then a border can be understood as an imagined line. In other words, human beings create borders by "connecting materiality and symbolic meaning" (Reuber 2012, 67).

Though immaterial and artificial, borders have practical consequences for people. Indeed, their creation needs to be understood as a manifestation of power that demarcates and organizes a space. This includes ordering the people that are located within such space, along with their language(s), culture(s) and way(s) of life (Reuber 2012, 56-59). Consequently, first, they determine and make visible who is inside and who is outside; thus, they have an identity component and act as metaphorical markers of belonging, delineating and shaping people's identities (Kaplan 2000, 46). Second, by molding membership in the community, borders affect people's rights and options (Wlasak 2017).

There are different types of borders. Though the notion of border is mostly associated with the political borders separating states, there are also administrative borders between substate units, like regions, provinces, and other territorial entities. Moreover, there are cultural borders that may be linguistic and religious; like political borders, Andrén and Söhrman $(2017,1)$ argue that even cultural borders are human artefacts that change over time and are constructed through narratives and practices. Furthermore, though "it is not always possible to classify them in such a strict manner," cultural borders "are more visible than ever" (1).

These political, administrative, and cultural types of border can overlap, crosscut, and intersect. Indeed, borders have been instrumentalized by nationalist projects that fostered processes of cultural homogenization (Oates-Indruchová and Blaive 2014, 197). Political borders can thus be culturalized whereas cultural borders can be politicized (Andrén and Söhrman 2017, 5). Incidentally, it is also possible that an individual could be inside one border but outside the other, a condition epitomized by the experience of members of national minorities, located within the political borders of the state but often (self-)perceived to be outside the cultural borders of the nation.

In the South Tyrolean case, three types of borders are particularly relevant and will be the focus of this article: these are the political border between Italy and Austria; the administrative border that defines and divides the two Italian provinces of South Tyrol and Trentino (also Province of Trento), which together form the region Trentino-South Tyrol; and the cultural-linguistic border among the Italian-, German-, and Ladin-speaking communities. These borders at times overlap, like the Italian borders and part of the boundaries of the South Tyrol province, but only partially. In particular, the cultural-linguistic border departs from the political and administrative border. Not only German, Ladin, and Italian speakers live in South Tyrol; there are also small Ladin and German-speaking communities in Trentino (as well as in other Italian regions). Because of this lack of convergence among its borders, South Tyrol, as a borderland, is, using Kaplan's words, "messy" and a "zone of confusion" (2000, 46). 
Since they are artificially created, borders are not fixed and static. On the one hand, they are often contested and the source of tensions and conflicts, if not wars. On the other hand, they can change: they appear and they can thus disappear, be moved, be redrawn, or acquire and lose importance. These shifts occur as the result of various social dynamics and the potential agency power of several type of actors, including state and civil society, as well as regional, national, transnational, and international forces (Oates-Indruchová and Blaive 2014, 195). Meanwhile, scholars have highlighted processes of de- and reterritorialization of borders, and, in this regard, borderscape has become a trendy concept to grasp the fluidity and fluctuation of the border areas and the politics behind them (Brambilla 2015).

\section{Background to the Case Study}

Such dynamic processes are present in the history of the South Tyrolean political, administrative, and cultural-linguistic borders analyzed in this contribution. These three types of borders have been greatly shaped by historical events and have experienced important developments in the past one hundred years. For centuries, the current border between Italy and Austria, represented by the Brenner Pass, was not actually a political border. Neither was the adjacent territory south of the Brenner a distinct entity until the beginning of last century (Obermair 2018, 22). Indeed, since the Middle Ages, South Tyrol, Trentino and the Austrian region of Tyrol were all part of the County of Tyrol, located within the Habsburg Empire. ${ }^{2}$ Only at the end of the 19 th century were claims made by a few Italian nationalists, in primis Ettore Tolomei, that the Brenner Pass was the natural border of Italy for strategic, military, and geographical reasons. To this assertion, Tolomei added a cultural-ethnic argument: the claim that the German-speaking inhabitants of South Tyrol were mostly of Latin origins who underwent a historical process of being "Germanized." In contrast, many other nationalists, like Cesare Battisti, laid a territorial claim to only the mostly Italian-speaking Trentino and the border at the site of the Chiusa di Salorno/Salurner Klause, a narrow section of the Adige Valley near the village of Salorno/Salurn. However, during WWI as part of the 1915 London Pact, the Triple Entente offered not only Trentino but also South Tyrol (among other territories) to the Italian state in exchange for its alliance. After the war, with the 1919 Treaty of Saint German, South Tyrol was therefore annexed by Italy as a spoil of war, fixing the political border at the Brenner Pass.

Since then, the Brenner border has never been seriously contested militarily or politically due to geostrategic reasons, ${ }^{3}$ despite the fact that various requests for self-determination and changing the border were raised by the German-speaking population and endorsed by the Austrian government (after WWI, after WWII, and during the tensions in the 1950s and 1960s). During WWII, Mussolini and Hitler did not want to risk their alliance for few thousand South Tyroleans and instead made an agreement that gave South Tyrolean German speakers the choice to immigrate to the Third Reich (the so-called Option). Following WWII, debates on the border at the Brenner reflected the various interests of the great powers (including the fact that with the unfolding of the Cold War the USA did not want to antagonize Rome). Thus, Italy and Austria were forced to make an agreement, the socalled De Gasperi-Gruber Agreement, through which South Tyrol remained part of Italy and the Italian government committed to providing political autonomy and protective measures to the German-speaking population.

The administrative border between South Tyrol and Trentino was created in the 1920s by the fascist regime, a period during that the two Provinces made up the region Venezia Tridentina. The border acquired political salience and became contested, mostly due to its political weight rather than its geographic location after WWII. This is when the Italian government began to implement the political autonomy mandated by the De Gasperi-Gruber Agreement. The First Statute of Autonomy enacted in 1948 transferred some municipalities inhabited by German speakers from Trentino to South Tyrol. Moreover, it provided territorial political autonomy not to the mostly German-speaking South Tyrol but to the combined region Trentino-South Tyrol (composed of the Province of Trentino and South Tyrol), wherein German speakers were a minority. Thus, South 
Tyrol administrative borders were mostly irrelevant. This fact, together with the weak implementation of other measures of the statute by the Italian government, sparked ethnic tensions in the 1950s and 1960s during which the German-speaking community demanded political autonomy for South Tyrol, as epitomized in the slogan loss von Trient (away from Trento). The tensions led to the 1972 Second Statute of Autonomy through which political autonomy was transferred from the regional level to the provincial level.

However, the border of the South Tyrol autonomy does not overlap exactly with the culturallinguistic border between Italian and German speakers. Until the end of WWI, South Tyrol was mainly inhabited by German speakers together with a small Ladin community that was concentrated in few mountain valleys; even at that time, though, there were some few thousand Italian speakers who, for the most part, did not identify with the Italian state (Peterlini 1996). Italian speakers started to migrate to South Tyrol (mainly to its urban areas) from other parts of the peninsula after WWI, primarily as the result of fascist policies to Italianize the territory. ${ }^{4}$ As a consequence, Italian speakers increased from about 7,000 (3\% of the population) in 1910 to more than 104,000 in 1943 (35\%). During the years of the First Statute of Autonomy, the number of Italian speakers continued to increase, though with a slower pace. This influx of Italian speakers was labelled the Todesmarch (March of Death) by the German-speaking population, who feared being outnumbered, contributing to ethnic tensions. After the enactment of the Second Statute of Autonomy, the number of Italian speakers has decreased a bit and has stabilized in the past decades. According to the last census of $2011,69.4 \%$ of the South Tyrolean population belonged or aggregated to the German-speaking group, $26.1 \%$ to the Italian-speaking group, and $4.5 \%$ to the Ladin group. Italian speakers live mainly in the urban areas, especially Bolzano/Bozen, South Tyrol's capital (which has a majority of Italian speakers and accommodates around $60 \%$ of the Italian-speaking group). The Ladin population is still concentrated in a few mountain valleys as well as some adjacent areas located in the province of Trentino and the region of Veneto. In the province of Trentino, as in other parts of Italian Alps, there are also some small historical Germanic communities consisting of Mocheno and Cimbrian speakers.

The cultural-linguistic border among Italian, German and Ladin speakers further recedes when considering the presence in South Tyrol of mixed persons. This group comprises the children of parents belonging to different South Tyrolean linguistic groups who are not counted as such in censuses. In 2011, this group was estimated to be between 25,000 and 35,000 of a total population of a bit more than 500,000 people (around 5\%-7\%) (Pallaoro and Colletti 2013, 119).

\section{Analytical Framework}

The political, administrative, and cultural-linguistic borders hold great historical weight in South Tyrol. This relevance endures even though their history shows how these borders are each an "arbitrary" and "impermanent" boundary rather than a "destined marker for all time" (Fuller 2018, 111). Returning to the theoretical discussion about borders, what is the meaning and value of such borders? On the one hand, the mass media circulates news and imaginaries regarding the construction of walls to rearticulate borders and governmental decisions to impede NGOs' boats loaded with migrants to dock in ports in the attempt to stop the influx of migrants. Thus, there appears to be a tendency to give a negative connotation to the notion of borders. In this regard, nationalism studies often consider borders as lines dividing nations and communities (or reinforcing existing fractures), looking at how people cope with them (Huttenbach 1996; Kind-Kovacs 2014). In scholarship on borders, Wlasak (2017) stresses how borders are the result of a human need for protection and a defensive tool. Along the same lines, Kreide (2019) sees borders as mainly walls and fences that block people's way and create obstacles to membership in a community. Furthermore, according to Kreida, borders today are no longer simple lines but a complex social institution, composed of a network of technical and administrative control mechanisms that restrict people's options and present some outsiders (migrants) as threats. 
In reality, a border is not necessarily something negative in and of itself $a$ priori. Historically, for people escaping political oppression, wars, and misery, borders have even represented a door toward freedom, safety, and a better life. In the same fashion, the Brenner border, since its establishment, has always been an area of passage for people "on the run": to those South Tyroleans who opted to migrate to the Third Reich during WWII, to those who returned at the end of the war, to Italian migrants riding trains north in search of a better life in Germany in 1960s, to people escaping the war in former Yugoslavia in the mid-1990s, and to the more recent influx of asylum seekers in the past years (Weissensteiner 2016). Thus, borders are not necessarily a negative element, linked indelibly to factors such as closure, tensions, and conflicts. Borders can be seen in positive terms; in particular, they can be seen as places where differences meet, a fact that is often recognized as a source of enrichment for human society. This positive understanding lays behind the several cross-border cooperation initiatives that have developed in Europe since the 1950s (Engl 2016).

Borders become problematic when their crossing is made difficult, that is, when they are closed and become coercive, tracing boundaries of exclusion. The issue is not to put in question the existence of borders but rather to understand the dynamics through which they are framed to bring closures and exclusions. At stake is the notion that there are different understandings of borders that are operationalized at different moments to meet certain needs for certain groups. Understanding the conditions under which the idea of borders is invoked and certain outsiders are perceived as threats reveals internal dynamics of belonging and processes of othering.

In this regard, the field of security studies provides some useful conceptual tools to analyze how borders become a negative factor. In particular, I refer to the concept of securitization and its antithesis desecuritization. As theorized by the so-called Copenhagen School of security studies, securitization refers to the process through which an issue is considered as an "existential threat, requiring emergency measures and justifying actions outside the normal bounds of political procedure" (Buzan, Wæver and de Wilde 1998, 23-24). This process does not refer to an objective state that can be measured. Indeed, an issue is securitized "not because a real existential threat exists but because the issue is presented as such a threat" (24). Securitization is thus a social construct. For the Copenhagen School the process of securitization is a "speech act," according to which, "by saying the words, something is done" (26). Language has performative power, and securitization is an effect of mobilization, in which language plays a crucial role. This speech act does not happen in a vacuum; thereby the Copenhagen School looks at whether a public audience accepts and endorses such securitizing discourses.

However, scholars have long debated on where and how processes of securitization take place, and the concept has been subjected to other theorizations. A sociological variant of studies on securitization highlights the role of social and legal practices; historical narratives; social, cultural, and political contexts; public images; media; institutions; and physical acts (Jutila 2015). The socalled Paris school applies biopolitics, focusing on rationalities of governance, methods of social control, and surveillance technologies (Bigo 2002).

Scholarship on securitization has thereafter turned to thinking about tackling the process through which an issue is securitized (Balzacq 2015). In this regard, as the antithesis of securitization, desecuritization is considered a performative action by which an issue is no longer considered as a threat and is taken out of the emergency mode, loosening the friendenemy distinction. There is, however, a variety of understandings of desecuritization (Hansen 2012). Critically, (de)securitization is understood as a continuum, constituted by moves and countermoves, and in this regard, scholars have also spoken of resecuritization, when an issue that was desecuritized becomes securitized again (Jaroszewicz, Krakhmalova, and Grzymski 2020).

The concept of securitization has been shown to bear explanatory power when applied to a wider range of issues, including ethnic tensions, national identities, and minorities issues (Butler 2020; 
Jutilia 2015; Trédaniel and Lee 2018). It has been used to show how specific minorities have been securitized or how parties involved in tensions/conflicts have performed as securitizing actors (Olesker 2014; van Willigen 2010). Expanding on this work, I argue that securitization can be employed to develop a framework for analyzing border politics as they are shaped by and shaping interethnic relations. The concept of securitization improves our understanding of why and how borders become exclusionary, become restrictive, foster the creation of otherness, and when these processes are likely to take place. In this way, I situate securitization within boundary-making processes, since the concept is based on the fostering of a friend-enemy distinction that shapes political identities and the boundaries of the community. This framework also draws from Bilgin (2010, 82, 87) who speaks of an "identity/security nexus" and Alvarez who refers to "a sort of boundary-producing political performance" $(2006,77)$. Securitization delimits the group to be secured, the threatening group, and what is not a threat, as well as who is an insider and who is an outsider. In other words, securitization is a process of othering that creates and defines boundaries and categories of inclusion and exclusion.

I argue that borders become problematic when securitizing processes are in place and when borders themselves "become elements of securitization" (Kreide 2019, 46). Processes of securitization of borders can unfold in three ways. First, borders are securitized when whoever or whatever is outside of the border is perceived as a threat by those who are on the other side. In this case, borders become (from one side) a protective tool that shields from dangerous "outsiders," while at the same time represent a material obstacle for those who aim at crossing them. In relation to this, second, a border is securitized when those inside consider the border as weak and unable to perform its supposed protective function. Third, conversely, borders are securitized when being on what is considered as the wrong side of the border is perceived as a threat. In this latter case, borders and their geographical location are considered by themselves dangerous. Through processes of securitization, borders are framed in negative terms. They become sites of friction and separation, being used as exclusionary and restrictive tools. In contrast, desecuritized borders acquire positive connotations as places of encounters and exchange where insiders and outsiders meet without fear.

I apply these different patterns of securitization to characterize the political, administrative, and cultural-linguistic borders of South Tyrol. Combining the Copenhagen School approach with the sociological variant of studies on securitization, I consider political discourses and practices of securitization surrounding South Tyrolean borders. As briefly presented above South Tyrolean borders have been historically contested at different times and different stages. From a securitization perspective, the borders were subject to securitizing actions: the location of the political border at the Brenner Pass was considered dangerous by the German-speaking population; the arrival of Italian-speakers challenged its cultural-linguistic borders; and the administrative borders of the autonomy were considered as lacking. In the next two sections, I analyze how, following the Second Statute of Autonomy, historical processes of securitization have been mitigated in South Tyrol and its borders have been desecuritized. Then I show how, in the past few years, we have been witnessing a process of resecuritization of South Tyrolean borders.

Before turning to the analysis, a brief methodological note is in order. The study combines four sets of data. First, it relies on secondary resources, drawing particularly from previous academic literature and empirical studies on South Tyrol. Existing data are re-elaborated and reinterpreted in light of the specific research focus. Second, the study uses discourse analysis, conducted by the author, of political speeches and texts from the past decade (2010-2020), particularly electoral programs and documents of main South Tyrolean political parties, in order to highlight securitizing speech acts. Third, it draws on reports by local NGOs dealing with and monitoring the issue of asylum seekers in the province to trace current practices of securitizing South Tyrolean borders. Last, when available, a handful of public opinion surveys are used as a proxy to measure public endorsement of (de)securitizing moves. 


\section{From Desecuritizing borders ...}

Looking at the South Tyrolean borders, we can trace processes of desecuritization following the 1972 Second Statute of Autonomy. The statute put in place a "complex power-sharing system" that is considered one of the most successful examples to dissolve ethnic tensions and protect minorities (Wolff 2008). The system combines territorial autonomy with several language rights and corporate consociational mechanisms, which aim at recognizing and protecting the German (and Ladin) speaking groups, thereby providing them access to power while fostering elites' cooperation. The statute instituted an extensive territorial political autonomy that ranges across several policy fields for South Tyrol, where German speakers are the majority. In the province, there is mandatory bilingualism (trilingualism in Ladin areas) of public signs, toponyms, public documents, and public officers. The main corporate consociational mechanisms are:

- proportional representation of the linguistic groups in legislative and executive provincial government bodies

- a sort of veto power for the linguistic groups in matters regarding the vital interests of a group

- the so-called "ethnic quota system," namely, the distribution of public employment and public resources among the linguistic groups in proportion to their numerical strength ${ }^{5}$

- cultural autonomy in the form of separate cultural offices for language groups, education in the mother tongue of the pupils, and compulsory teaching of the other main language spoken in South Tyrol, achieved through the maintenance of separate school systems: Italianlanguage schools, German-language schools, and trilingual-schools in the Ladin valleys.

This system has indeed proved effective: by guaranteeing the protection of the German- and Ladinspeaking population, diminishing ethnic tensions, and providing for peaceful cohabitation. An additional element of its success, as I argue here, is that it has contributed to overcoming a securitizing view of the South Tyrolean borders. Thanks to the high level of autonomy and cultural and linguistic rights, the political border at the Brenner Pass (thus, the fact that South Tyrol is part of the Italian state) is no longer seen in negative terms as a threat by most of the German-speaking population. The German-speaking group has been guaranteed the maintenance of its linguistic and cultural characteristics as well as control over its own affairs within the administrative borders of the political autonomy. In this way, the German-speaking group was reassured about its cultural borders and its existence, even as part of the Italian state, and it ceased to fear the presence of Italianspeakers in the province. As a result, most of the German-speaking population has dropped their secessionist claims though some nationalist forces claiming the right of self-determination persist. In other terms, we witness an interplay between developments concerning the various South Tyrolean borders. Desecuritization processes of the administrative border have consequences for the political and cultural-linguistic borders as well.

At the same time, the presence of the German-speaking community is not perceived as a threat by the Italian-speaking group. To be sure, the fact of having become a minority within the province has caused some issues, what has been called the "uneasiness" of the Italian population (Carlà 2019b; Pallaver 2013). However, the consociational mechanisms have protected the rights of Italian speakers living in South Tyrol, who were not left to the mercy of the majority German-speaking group (Pan 2016, 382; Benedikter 2008, 75).

This process of desecuritization of South Tyrolean borders emerges in South Tyrolean political discourses. The Südtiroler Volkspartei (SVP), the main party representing the German-speaking population, has long stressed the cultural link between South Tyrol and Austria/Tyrol, but the SVP also refers to the overcoming of political borders through the strengthening of the autonomy and cross-border institutions within a Europe of regions and peoples (SVP 2016; 2018). Furthermore, most South Tyrolean political forces see the coexistence of different linguistic groups in the province and their cultural-linguistic borders in a positive light rather than in confrontational threatening terms. Even Die Freiheitlichen, one of the main nationalist political forces that aims at 
the self-determination for South Tyrol and challenges the political border, have a desecuritized understanding of the cultural-linguistic borders, including the Italian-speaking group in its vision for South Tyrol. Indeed, according to the party, "in an independent South Tyrol all three autochthonous ethnic groups [German, Ladin, and Italian] would make up the South Tyrolean people" (Die Freiheitlichen 2018, author's translation).

For the other side of the language political spectrum, there are right-wing political forces in the Italian-speaking political arena that stress the need to protect the interests of the Italian-speaking group. However, today they deemphasize the conflictual aspects of the relationship between the groups and no longer question the salient elements of South Tyrolean autonomy, as they had done in the past. These desecuritizing discourses of cultural-linguistic borders are matched in public attitudes toward plurilingualism and cultural diversity. According to a 2015 survey, $77.9 \%$ of people in South Tyrol think that the presence of more linguistic groups in the province is an enrichment or could be an enrichment under some conditions (ASTAT 2015, 181).

At the same time, it should be noted that the same consociational mechanisms have established a society composed of three clearly distinct linguistic groups. These mechanisms maintain a degree of divisions among the groups in many aspects of social and political life, since each community has created its own structures such as political parties, associations, and mass media, thereby limiting social contacts. Yet, in past years, there have been improvements in terms of increasing trust, interaction, and cooperation, and the development of interethnic civil society initiatives (Pallaver 2008 ; 2014). In other terms the cultural-linguistic border remains characterized by some exclusion that is revealed particularly in the political speeches within the German-speaking political arena. The SVP maintains the idea that each linguistic group needs to consolidate its own culture before interacting with other cultures, whereas more nationalist parties further stress the need to preserve and maintain distinctions for each group, avoiding "egalitarian uniformity porridge" and measures like mixed schools (SVP 2016, 13; Die Freiheitlichen 2018, author's translation).

Not surprisingly, in public opinion surveys on the sense of belonging, there are great differences among the linguistic groups in terms of identification. In 2014, 80.7\% of the German-speaking population identified with the term "Südtiroler/Sudtirolese" (South Tyrolean), whereas the majority of the Italian-speaking group identify as "Italian" (59\%) and in minor terms as "Altoatesino" (18.7\%) (the Italian term for South Tyrolean) and "Sudtirolese di lingua italiana" (South Tyrolean of Italian language) (16.9\%). Nevertheless, it should be noted that most of the South Tyrolean population identifies with the territory and some persons have chosen postnational, cosmopolitan definitions like "European" (17.2\%) and "citizen of the world" (11.3\%) (ASTAT 2015, 170). 6 This development might indicate a further desecuritization of the cultural-linguistic border, in the sense that its weight might slowly be eroding.

At the same time, both the Italian and Austrian governments have marginalized securitizing perspectives of the political border at the Brenner Pass, at least vis-à-vis the past ethnic tensions. The Italian state no longer fears secessionist and territorial claims by the German-speaking population and the Austrian government. Conversely, since the De Gasperi-Gruber Agreement, Vienna was recognized as the protector of its kin people in South Tyrol-a role that it played during the ethnic tensions and was restated in the developments concerning the Second Statute of Autonomy. Furthermore, the border itself was emptied of its weight through a series of cross-borders initiatives. The De Gasperi-Gruber Agreement foresaw measures to dilute the importance of the border; these measures include mutual recognition of degrees, free passage and good transit between North and East Tyrol throughout South Tyrol, and facilitating frontier traffic and exchange of goods. Crossborder activities have further developed over the past two decades, epitomized by the creation in 2011 of the European Grouping for Territorial Cooperation 'European Region Tyrol-South TyrolTrentino' to develop and coordinate common policies. Meanwhile, with the development of the EU and the Schengen Area (Austria joined in 1995), controls at the Italian-Austrian border were removed, and the border became practically meaningless. A better way to put it is that the Brenner Pass became a dormant border. This dormancy is transient, however, since article 25 of the 
Schengen code allows member countries the possibility of restoring temporary and exceptional border controls in case of serious threats to public order or internal security. This exception will be the source of resecuritization as we see later on.

As further evidence of these desecuritizing dynamics, a recent study presents the attitudes toward borders of representatives of municipalities at the borders within the European Region Tyrol-South Tyrol-Trentino (the political border between Italy and Austria and the administrative border between South Tyrol and Trentino). In the study, it emerged that the political border is still strongly felt in the collective memory of the population, whereas the administrative border is less prevalent but strongly associated with the linguistic border. More relevantly, the representatives of municipalities associated the notion of border mostly with positive elements, such as "possibilities" and "point of encounters," to a lesser extent with symbolic and identitarian elements, and to the least extent with ideas such as "obstacle," "conflict zone" and "place of refugee." However, differences persist across some municipalities at the political border and some of those at the administrative border (Alber et al. 2019, 49).

\section{... to Resecuritizing Borders}

The complex power-sharing system put in place in South Tyrol has fostered a desecuritized environment where the South Tyrolean borders have lost their conflictual weight. However, societies are never "finished and complete" (Salat 2014, 137) but in constant transformation. In addition to the presence of mixed persons in South Tyrol, the past two decades have witnessed the arrival of many migrants from foreign (EU and non-EU) countries. From only 5,099 migrants in 1990, most of whom came from Germany and Austria, the migrant population has increased rapidly. At the end of 2018, there were 50,333 migrants from more than 130 countries, representing $9.5 \%$ of the total population. One-third of these migrants came from EU countries, another $30 \%$ from other European countries, $19.3 \%$ from Asia, and 14.1\% from Africa. The main nationalities are Albanian (5,767 / 11.4\%), German (4,500 / 8.8\%), and Moroccan (3,650 / 7.2\%), followed by Pakistani (3,550 / 7.0\%) and Romanian (6.6\%) (ASTAT 2019).

This demographic shift intersects with ethnic politics in South Tyrol and its consociational system in different ways. Crucially, it has sparked a process of resecuritization of South Tyrolean borders, affecting in particular the cultural-linguistic borders between South Tyrolean linguistic groups and the administrative border of the province. Indeed, the presence of foreign migrants clashes with the frame of a society composed of three distinct linguistic groups, raising concerns about their cultural-linguistic borders as well about the strength of the borders of South Tyrolean autonomy. The topic of migration has led to the circulation of questions: "Into which group will migrants integrate?" and "Do they constitute a new fourth group?" Consequently, there emerges at times a vision of migrants as a demographic challenge if not a threat.

Indeed, in the past two decades, South Tyrolean political discourses on the topic of migration have been characterized by different arguments that present migration as a danger and a spark for tensions. As in many other European countries and regions, there are political forces that link migration to the anxiety of cultural alienation, as well as to issues of criminality. There are references to welfare chauvinism and the fear that migrants will take over socioeconomic resources. Migrants, especially those from Muslim majority countries, are the new dangerous Other, a foreigner who must be made to adhere to the local cultures and values. In this type of political discourse, this new Other seems to blur the cultural-linguistic borders among South Tyrolean groups, since, compared to migrants, they share Christian/European heritage and values.?

From available public opinion surveys, it seems that these securitizing discourses found a reasonable degree of endorsement in part of South Tyrolean public opinion. According to a 2007 survey, for almost half of the South Tyrolean population, migration from non-EU countries is among the three main problems of the country (ASTAT 2008, 1). Furthermore, in $201648.9 \%$ of South Tyroleans think that increasing migration has led to the spread of terrorism and crime, and 
29.9\% disagree with the statement that migrants' presence is positive because it allows them to interact with other cultures (35.5\% of the population agrees and $34.6 \%$ neither agree nor disagree) (ASTAT 2018).

At the same time, some political discourses reflect a demographic fear, in which the presence of migrants alters the balance between Italian and German-speaking groups. In particular, Germanspeaking political forces are worried that migrants have integrated mostly into the Italian-speaking group and "will become tomorrow's Italians," endangering the German character of South Tyrol (Knoll 2011, author's translation). As stated in the 2018 program of a German-speaking nationalist political force, migration "must thereby be compatible with the special ethnic structure of the country, the cultural characteristics of South Tyrol" (Die Freiheitlichen 2018, author's translation). Moreover, migration has been seen as creating tensions between the Italian and German groups in specific regard to the South Tyrolean consociational system. As stated in the 2018 electoral program of the SVP, "the migration movements of recent years have posed great challenges to th[e] orderly coexistence" of the three South Tyrolean linguistic groups (SVP 2018, author's translation). In this context, some political forces have used migration to argue that some features of the South Tyrol consociational model (like the ethnic quota system) should be updated and modified, since migrants are "the main indicators that our society is very different from the rough schematization imposed by the ethnic proportion" (Foppa n.d., author's translation). Finally, the topic of migration sparked discussions on the need to increase provincial competencies on matters of migration or adapt national integration policies to the specific cultural features of South Tyrol, creating conflicts between the South Tyrolean government and the Italian state. At times, such discussions are linked to the claims of German-speaking nationalists that the political autonomy and its administrative borders are not sufficient to protect the German-speaking group, and to their secessionist desires. ${ }^{8}$

Securitizing discourses combined with policy practices and resulted in two main implications. First, the South Tyrolean government has tended to focus on containing the impact of migrants on South Tyrolean society, including the equilibrium between South Tyrolean linguistic groups. Secondly, there were clashes between the South Tyrolean and Italian governments. For example, particular attention has been given to measures for migrants to learn the local languages and culture while not integrating only with the Italian-speaking group. In 2009, when the national legislation required an Italian language test in order to obtain long-term residence permits and introduced the so-called accordo di integrazione (integration agreement)-a point system in which migrants declare their commitment to learning the Italian language (among other things) - the South Tyrolean government requested to have a German test and German classes as alternatives. The Italian government, however, only agreed to add optional German classes to the criteria of the integration agreement. As a reflection of the fear concerning migrant pressure on the welfare system, a provincial law passed in 2011 introduced limits to migrants' access to some social economic benefits. The Italian government appealed the law, and these limits were deemed unconstitutional by the Italian Constitutional Court. More recently, the province has adopted a policy of civic integration according to which access to some benefits is linked to proof of migrants' will to integrate and participation in measures to promote integration, such as learning Italian or German and attending classes on civic education.

To summarize, facing migratory flows and settlement within the province, South Tyrolean borders were resecuritized, thereby acquiring negative connotations. First, looking at the culturallinguistic borders, migrants become the new threatening Other in contraposition to local South Tyrolean groups. Second, this dangerous outsider affects and revamps issues surrounding the cultural boundaries among the South Tyrolean linguistic groups and their coexistence. Third, though to a lesser extent, migration puts in question the administrative borders of South Tyrolean autonomy. There emerges a push to increase claims around autonomy, wherein German-speaking nationalist forces see administrative borders as insufficient for the protection of South Tyrolean society. Current migratory flows bring back securitization processes surrounding South Tyrolean borders (especially the cultural-linguistic and administrative ones). 
This rapidly resecuritizing environment faced a new crisis in 2014 with the increase of asylum seekers and refugees into South Tyrol, following patterns seen in the rest of Italy and other EU countries. Whereas in 2013 there were 58 asylum seekers in the province, in 2017 provincial reception structures processed between 1,400 and 1,650 persons, mostly from countries in Central Africa as well as Iraq, Afghanistan, Pakistan, and Bangladesh. The following years numbers began to decrease (Saltarelli and Weissensteiner 2016, 131; Provincia Autonoma di Bolzano and Eurac Research 2017; Dalla Pria 2019). Since 2014, in Italy, asylum seekers are distributed among the various regions and South Tyrol receives $0.9 \%$ of the asylum-seeking population. Moreover, South Tyrol is a critical transit area for many asylum seekers who seek to reach central- and northEuropean countries to make their asylum claims. This passage means crossing the Brenner Pass, but some asylum seekers ended up stopping temporarily in South Tyrol, especially in Bolzano/Bozen. At a later stage there was an influx of asylum seekers who came to South Tyrol/Italy by way of Austria. It is estimated that in 2016 some hundreds of migrants were transiting every day in the train stations of Bolzano/Bozen and Brenner. By the following year, the number decreased to a few dozen or less (Rabini 2018; Provincia Autonoma di Bolzano and Eurac Research 2017).

The recent influx of asylum seekers intersected with the ongoing process of resecuritization of South Tyrolean borders that had been sparked by the arrival of foreign migrants into the province over the past two decades. In particular, the political borders were affected by this development. In South Tyrolean political discourses, the concept of asylum seekers has been blended with other categories of people-from refugees to undocumented migrants to economic migrants-as part of an assemblage of people that is perceived as a threat. In their analysis of debates in the South Tyrolean parliament in 2015-2016, Engl and Wisthaler $(2020,478)$ show that discussions on refugees and asylum seekers concentrated on measures to prevent their settlement in the province or limit the movement of people, including restricting access to social benefits. This insight is further confirmed when looking at the party programs for the last 2018 provincial election, where discourses have focused on how to control the border, the need to "actively manage migration and, above all, stop illegal immigration" (SVP 2018, author's translation), or the fact that in general "migration needs control" (Die Freiheitlichen 2018, author's translation), leaving aside issues concerning processes of migrant integration. At the same time, even more than in the past, migrants have been linked to crime and pressure over the South Tyrolean welfare and education system, where, for example, South Tyrolean children "feel like foreigners in their own home" (Lega n.d., 3, author's translation). However, alternative desecuritizing discourses developed as well. As happened in the past with earlier migration flows, some of these discourses link the topic of migrant diversity with the need to overcome the divisions and borders among South Tyrolean linguistic groups and create a more inclusive society.

Securitizing discourses are in part manifested in policy practices. This was seen in the decisions by the provincial government surrounding the reception of refugees and asylum seekers. At first, the province relied on big reception structures, mostly in Bolzano/Bozen, the city where most of asylum seekers had been concentrated until the end of 2016 (Rabini 2018). ${ }^{9}$ In these structures, many necessary services, like psychological support, and proper accommodation where not guaranteed and there were problems of public order at times. In a second stage, few smaller reception structures were organized in some municipalities, whereas in Bolzano/Bozen continued to operate with a sense of emergency (Saltarelli 2017; Weissensteiner 2016). Furthermore, many people (in 20152016 about 330 persons, decreased to an average of 180-200 in 2017) have remained outside of the system, sleeping in parks and under bridges, especially in Bolzano/Bozen (Dalla Pria 2018; Rabini 2018). Observers saw in these actions a model of reception based on the principles of precarity and dissuasion so that people would not be attracted to come and take roots in South Tyrol (Saltarelli 2017; Fondazione Alexander Langer, ASGI, and Antenne Migranti 2017, 13). ${ }^{10}$

In other terms, there continues a process of securitization that sees migrants and refugees as a threatening Other that should be excluded. Furthermore, the issue of asylum seekers and refugees has recast the questions about the strength of the administrative borders of South Tyrol. Indeed, it 
reinforced the debates around the competence of provincial authorities to manage the migratory flows and claim-seeking around a further shift of power from the state to the province (Engl and Wisthaler 2020, 479).

More relevant, in the case of asylum seekers, it is the political border at the Brenner Pass that saw most of the developments with the Austrian government acted as the main securitizing actor. Vienna put in place a series of securitizing practices against the perceived dangers of asylum seekers coming from the south side of the border, inverting its historical desire to dilute barriers between the German-speaking South Tyrolean population and its kin state. Indeed, the Austrian government aimed at rearticulating the border and reasserting its control over it. At the beginning of 2016, the chief of the Tyrolean police (in Austria) stated that between 200 and 300 persons were entering into Tyrol on a daily basis from the Brenner Pass with the prospect that this number would increase to 700. Thus, according to the chief of the police, controls at the border were not to be excluded (Bandinelli 2016). A few weeks later, the Austrian head of government, Werner Faymann, announced the intention to apply article 25 of the Schengen code because the massive and continuous flux of asylum seekers was deemed a danger to public order and internal security. The intention was to reestablish controls at the Brenner Pass and eventually the other border crossing between South Tyrol and Austria. In April, Vienna announced the installation of new infrastructures to control the influx of people at Brenner from the south and to manage better the border.

The Austrian intent to reassert control over the border provoked a number of responses. There was criticism by EU and Italian politicians and various initiatives by the presidents of Tyrol, South Tyrol, and Trentino to mediate between Italy and Austria. There were also protests at Brenner that at times turned violent, with activists clashing with the police. EU Commissioner for Immigration Dimitris Avramopoulos refuted Vienna's securitizing move, stating that the current influx of migrants from Italy did not justify the reintroduction of border controls since it did not represent a threat to public order or internal security (Saltarelli and Weissensteiner 2016, 130). At the end, however, the Austrian intended measures did not materialize, though in summer of 2017 some Austrian politicians stressed again the need to protect the borders and even use the military for this purpose. Such statements were made mainly for political electoral propaganda (Facchini 2018).

Even if the heavy-handed threat of Austria did not come to pass, the securitization of the border was reflected in other practices. First, there was a marked increase in the number of controls along the Brenner route, especially along the train network. The Austrian police stopped thousands of undocumented people in Tyrol with the result that many were returned to South Tyrol. This followed a 1997 agreement between Austria and Italy (restated in 1999 and 2012) that allowed both countries to readmit informally (within 24 hours) or formally (within 8 days) undocumented people found near the border or within Tyrol and South Tyrol. Thus, many of the persons intercepted by the Austrian police were put on trains directed to Bolzano/Bozen or brought to Brenner. Most of the times, these readmissions followed informal procedures and questionable practices that some considered in violation of EU and national laws (Facchini 2018; Saltarelli and Weissensteiner 2015; 2016, 131; Fondazione Alexander Langer, ASGI, and Antenne Migranti 2017, 21, 72-78). Between 2012 and 2014 accepted readmission from Austria to Italy increased by more than $238 \%$, passing from 580 to 4,408 . In the following year, the rates decreased and, with the more recent flux of asylum seekers coming from Austria to Italy, inverted. In the first part of 2016, Italian police stopped 2,722 persons, and 674 were then readmitted in Austria (Saltarelli and Weissensteiner 2015, 124; 2016, 130; Fondazione Alexander Langer, ASGI, and Antenne Migranti 2017, 72).

Second, there was the activity of trilateral (German, Austrian, and Italian) police patrols that engaged in controls and passport checks on Italian trains that traveled from Italy to Austria and Germany. Created in 2011 to foster police cooperation, by 2014 these trilateral patrols were reinforced and reconceptualized in light of the new migration flows. They thereby worked daily and systematically on Northbound trains, forcing people without documents to disembark before reaching the border; this practice occurred frequently in Bolzano/Bozen, where the police force 
surveilled the train tracks (Saltarelli and Weissensteiner 2015, 122-123; Quadroni and Luppi 2017; Fondazione Alexander Langer, ASGI, and Antenne Migranti 2017, 78-80). During the controls, the use of racial profiling practices was observed; moreover, the actions by trilateral patrols were deemed to have some compliance issues with Schengen regulations (Fondazione Alexander Langer, ASGI, and Antenne Migranti 2017, 79; Saltarelli and Weissensteiner 2015, 123). In order to avoid these border controls, people started to travel with busses, attempted to cross the mountain pass on foot, or jumped onto freight trains, sometimes with fatal results (Facchini 2018).

Because of these border control activities, it seems as if the political border between Italy and Austria has been shifted and/or expanded in a southward direction, from Brenner to Bolzano/ Bozen. Indeed, many people did not even reach the Brenner Pass but were blocked at the city of Bolzano/Bozen, where they were "stranded" (Progetto Melting Pot Europa 2017). As explained by South Tyrolean NGO representative Karin Cirimbelli, "when they closed the Brenner in 2016, the border moved to Bolzano" (Facchini 2018, author's translation). In this regard, local observer and expert Salvatore Saltarelli speaks of a "mobile border" (Saltarelli 2017, author's translation). This development confirms Amilhat Szary and Giraut's observation of the "dissociation between border functions and border locations" $(2015,6)$. In this regard, scholars have long analyzed and criticized the process through which EU border and migration policies have been externalized and outsourced to neighboring countries (Williams and Mountz 2018). Developments at the Brenner/ Bolzano border show that processes of externalization happen within the EU as well. To summarize, the arrival of asylum seekers in the province combined with the ongoing processes of securitization of South Tyrolean borders sparked by recent migratory flows. In particular, we witnessed securitizing moves affecting and even reframing the political border at the Brenner Pass.

The process of securitization of the political border was further reinforced during the COVID-19 pandemic. Austria reacted to the coronavirus by unilaterally closing the borders with Italy as a means to control and stop the passage of Italian citizens. This had the effect of activating the infrastructures that had been created (but in the end not employed) to control the flow of migrants at the Brenner. It should be noted that many other countries within and outside the EU as well the EU itself have closed their borders, sometimes with unilateral decisions, other times in agreement with neighboring countries. There was no shortage of populist politicians who claimed "vindication for their longstanding emphasis on closing borders" or tried to make links between migrants and coronavirus (Bieber 2020, 7). However, on a practical note, closing the borders "has little chance of stopping" the spread of diseases; instead, such moves can have "unintentional perverse outcomes" by drawing attention away from more effective measures (Banulescu-Bogdan, Benton, and Fratzke 2020). At the Brenner Pass, the closing of the Italian-Austrian border to people from Italy and additional controls on any trains coming from the peninsula did not stop the spread of the virus in Austria. Meanwhile, it has only created economic and social distress.

Moreover, during the pandemic, some South Tyrolean nationalist forces took advantage of the political opportunity to reactivate their claims about the danger of the location of the political border at the Brenner Pass. In light of the initial severity of the pandemic in Italy and the harsh lockdown measures imposed by Rome, these politicians took some highly visible and symbolic actions to ask for self-determination and for moving toward south of the political border.

However, during the COVID-19 pandemic as well as during the influx of asylum seekers, crossborder initiatives were launched within the framework of the European Region that mitigated the process of the securitization of South Tyrolean political borders. In particular, to deal with common issues related to asylum seekers, the "Euregio Task Force" was created to foster exchanges and mediate conflicts among actors institutionally. During the pandemic, the South Tyrolean, Austrian, and Tyrol governments collaborated to acquire masks and protective equipment and introduce exceptions for cross-border commuters to the closing of the frontier. Moreover, cross-border cooperation led to the creation of a coordination group to exchange know-how on COVID-19, find common solutions, and foster solidarity and mutual help. These developments show that resecuritizing moves are not straightforward. As often happens with crisis, the response to the influx 
of asylum seekers and then the pandemic has been to re-enhance political borders as a security tool, yet the ongoing institutionalized cross-border cooperation contributes to weakening the barriers represented by political borders, thus sustaining desecuritizing processes. Indeed, these crossborder measures can be seen as acts of an "integrated governance" that has the effect of diluting the political weight of the border, fostering an "alternative political space" (Engl and Wisthaler 2020, 473,481 ). In addition, cross-border cooperation indirectly counterbalances the concern for South Tyrol's administrative borders, by giving a cross-border dimension to the political autonomy and in this way reasserting its capacity. Meanwhile, so far, the impact of cross-border cooperation on the cultural-linguistic borders seems limited.

\section{Conclusions: Securitizing Borders?}

This article innovatively combines insights from security studies, borders studies, ethnic politics, and migration to study South Tyrol as a case of shifting notions of sets of borders, in evermore diversifying regions. On the assumption that borders by nature do not necessarily have negative connotations, I used the concept of securitization (and desecuritization) taken from the field of security studies to elaborate a framework for analyzing developments affecting borders. I argue that the processes of securitization result in building tensions vis-à-vis borders, sparking dynamics of otherness through practices of restriction, coercion, and exclusion. This framework has been applied to a set of borders in the South Tyrol case: political, administrative, and cultural-linguistic.

As the result of the outcome of war and authoritarian decisions made during the fascist regime, the political, administrative, and cultural-linguistic borders in South Tyrol have been historically contested and processes of securitization entrenched in their creation and development. The Second Statute of Autonomy, together with international developments within Europe, tackled securitizing dynamics and fostered new perspectives on all South Tyrolean borders, which were no longer seen in negative terms as a threat. However, following contemporary migratory and demographic developments, we witnessed a cluster process of resecuritization of all types of South Tyrolean borders. First, migrants are perceived as new, dangerous Others that affect and bring challenges to the cultural-linguistic boundaries of the South Tyrolean population. Second, in addressing migratory movements, the extension of South Tyrolean political autonomy and the protective role of its administrative borders have been put into question. Third, concerns for the flow of asylum seekers and resulting Austrian pressure have resecuritized, if not even reframed, the political border at the Brenner Pass - a development further reinforced by the reaction to the spread of the coronavirus in Italy by the Austrian government and some South Tyrolean nationalist forces, though at the same time mitigated by cross-border initiatives.

Though on paper borders might be fixed, how they are perceived shifts based on processes of securitization and desecuritization. South Tyrol is an example of the fluctuation between positive and negative understandings of borders, from places of tensions, closure, and exclusion, to a point of encounter and enrichment, and vice-versa. In particular, the research highlights resecuritizing dynamics surrounding current migratory flows and how they impact diversified societies like South Tyrol and the politics of subnationalism in general. Indeed, processes of securitization concerning the arrival of migrants and asylum seekers replaced old issues regarding South Tyrolean political, administrative, and cultural-linguistic borders. Such processes challenge the status quo, affecting ethnic politics and minority accommodation in the province, for example reinvigorating debates on the balance among linguistic groups as well as the boundaries of political autonomy. Furthermore, by distinguishing and focusing on political, administrative, and cultural-linguistic borders, the analysis reveals how different types of borders are interlinked and how securitization dynamics affecting different borders intersect. At the same time, the research stresses that a key element of the concept of securitization is its effect on different types of boundaries among communities. Overall, bringing together diverse research fields, this contribution highlights the relevance of the concept of borders and dynamics affecting them in studies of diversified society and ethnic relations. Further 
comparative research with other borderlands could bring attention to additional contingent processes and unexamined linkages.

As a final note, the current pandemic has highlighted the problems inherent in processes of securitization of borders. Indeed, transnational challenges like COVID-19 (but also forced migration, climate change, the spread of plant pathogenic bacteria that can destroy entire agricultural sectors, and so on) require international solutions, wherein countries reach out to each other, "rather than focusing inward on protecting their own" (Banulescu-Bogdan, Benton, and Fratzke 2020). Thus, rather than securitizing borders and considering them as mainly defensive barriers, it might be better to frame them as loci of encounters and cooperation to tackle problems that in a globalized world are inherently common to all human beings. These problems persist regardless of which side of borders they emerge and cannot be contained nor addressed by single states or communities alone.

Acknowledgements. A first version of this article was presented at the 9th Annual Summer School on "National Minorities in Border Regions," a joint initiative of the European Centre for Minority Issues (ECMI) and Coppieters Foundation (Berlin 18 September, 2019). The author is grateful to Alexandra C. Budabin for her valuable help. The author thanks the journals' reviewers as well for their comments. The view expressed herein are those of the author alone. The author thanks the Department of Innovation, Research and University of the Autonomous Province of Bozen/Bolzano for covering the Open Access publication costs.

Disclosures. None.

\section{Notes}

1 Cambridge Dictionary, s.v. “border (n)," American Dictionary, accessed March 24, 2021, https:// dictionary.cambridge.org/dictionary/english/border.

2 The only period in which the historic Tyrol was divided along national borders was during the Napoleonic occupation, when the northern part down to Merano/Meran and Chiusa/Klausen was included in the Kingdom of Bavaria, the south part in the Kingdom of Italy, and the Val Pusteria/Pustertal in the Illyrian Provinces of the French Empire.

3 With the exception of the few years of Nazi occupation during WWII when South Tyrol was included, together with Trentino and the neighboring province of Belluno in the Operationszone Alpenvorland, officially part of the Italian Republic of Salò, but under direct German military control.

4 Fascist policies included the prohibition of the use of the German language in public spaces, the closure of German-language schools, and the Italianization of names.

5 This proportionality is calculated based on a declaration of linguistic belonging/aggregation (Italian, German, or Ladin speaker) released at the time of the census.

6 The survey had a multiple-choice format.

7 More research is necessary to investigate in depth how the presence of migrants and related securitization processes challenge and change the sense of belonging of the linguistic groups.

8 For further analysis on South Tyrolean political discourses on migration see Carlà $(2015,2019 a)$

9 For many years, South Tyrol did not enroll in the national system of reception of asylum seekers and refuges, the so-called SPRAR system (Sistema di Protezione per Richiedenti Asilo e Rifugiati/ Protection System for Refugees and Asylum Seekers), managed by local entities.

10 Notoriously in this regard, in September 2016 the province enacted a rule, the so-called circolare Critelli (Critelli Memo), which excluded some vulnerable people (those who were previously present in other EU countries and Italian regions) from access to reception services (see Fondazione Alexander Langer, ASGI, and Antenne Migranti 2017). 


\section{References}

Alber, Elisabeth, Alice Engl, Greta Klotz, and Ingrid Kofler. 2019. Governance transfrontaliera e vicinanza ai cittadini: Il ruolo dei comuni di confine nell'Euregio Tirolo-Alto Adige-Trentino. Bolzano: Eurac Research.

Alvarez, Josefina Echavarría. 2006. "Re-thinking (In)security Discourses from a Critical Perspective.” *asteriskos 1/2:61-82

Amilhat Szary, Anne-Laure and Frédéric Giraut. 2015. Borderities and the Politics of Contemporary Mobile Borders. Basingstoke: Palgrave Macmillan.

Anderson, Benedict. 1983. Imagined Communities. Verso.

Andrén, Mats, and Ingmar Söhrman. 2017. “Introduction." In Cultural Borders of Europe: Narratives, Concepts and Practices in the Present and the Past, edited by Mats Andrén, Thomas Lindkvist, Ingmar Söhrman, and Katharina Vajta, 1-17. New York: Berghahn Books.

ASTAT. 2008. "Problemi sociali percepiti dalla popolazione altoatesina." AstatInfo 32.

ASTAT. 2015. Südtiroler Sprachbarometer/Barometro linguistico dell'Alto Adige 2014. Bolzano: ASTAT.

ASTAT. 2018. Indagine sulla famiglia 2016. Bolzano: Provincia Autonoma di Bolzano.

ASTAT. 2019. “Popolazione straniera residente 2018." AstatInfo 30.

Balzacq, Thierry, ed. 2015. Contesting Security. London: Routledge.

Bandinelli, Alessandro. 2016. "L'Austria pronta a chiudere il Brennero." Alto Adige, January 16, 2016. https://www.altoadige.it/ cronaca/bolzano/l-austria-pronta-a-chiudere-il-brennero-1.410548. (Accessed April 15, 2020).

Banulescu-Bogdan, Natalia, Meghan Benton, and Susan Fratzke. 2020. Coronavirus Is Spreading across Borders, but It Is Not a Migration Problem." Migration Policy Institute, March 4, 2020. https://www.migrationpolicy.org/news/coronavirus-not-amigration-problem. (Accessed April 15, 2020).

Benedikter, Thomas. 2008. Europe's Ethnic Mosaic: A Short Guide to Minority Rights in Europe. Bolzano: Eurac Research.

Bieber, Florian. 2020. "Global Nationalism in Times of the COVID Pandemic." Nationalities Papers. Published online ahead of print April 7, 2020. doi:10.1017/nps.2020.35.

Bigo, Didier. 2002. "Security and Immigration: Toward a Critique of the Governmentality of Unease.” Alternatives 27:63-92.

Bilgin, Pinar. 2010. “Identity/Security.” In The Handbook of New Security Studies, edited by Peter. J. Burgess, 81-89. London: Routledge.

Brambilla, Chiara. 2015. "Il confine come borderscape." Intrasformazione 4 (2): 5-9.

Butler, Michael J., ed. 2020. Securitization Revisited. London: Routledge.

Buzan, Barry, Ole Wæver, and Jaap de Wilde. 1998. Security: A New Framework for Analysis. Boulder: Lynne Rienner Publishers.

Carlà, Andrea. 2015. “Tensions and Challenges between New and Old Minorities: Political Party Discourses on Migration in South Tyrol." In Migration in Autonomous Territories, edited by Roberta Medda-Windischer and Andrea Carlà, 65-99. Leiden: Brill.

Carlà, Andrea. 2019a. "Fear of 'Others'? Processes of Securitization in South Tyrol." Research and Science Today 2 (18): 9-25.

Carlà, Andrea. 2019b. “South Tyrol: A Model for All? The Other Face of Minority Accommodation.” Europäisches Journal für Minderheitenfragen 1/2:141-167.

Dalla Pria, Federica. 2018. “Lungo la rotta del Brennero: il modello di accoglienza." In Dossier Statistico immigrazione 2018, edited by IDOS, 147-148. Roma: IDOS.

Dalla Pria, Federica. 2019. "La creazione dell'illegalità.” Il Cristallo 1:111-117.

Die Freiheitlichen. 2018. Das freiheitliche Wahlprogramm zur Landtagswahl 2018. https://die-freiheitlichen.com/wp-content/ uploads/2018/09/Wahlprogramm-LTW18-S\%C3\%BCdtirol-in-sicheren-H\%C3\%A4nden.pdf. (Accessed April 21, 2021.)

Engl, Alice, and Verena Wisthaler. 2020. "Stress Test for the Policy-Making Capability of Cross-Border Spaces? Refugees and Asylum Seekers in the Euroregion Tyrol-South Tyrol-Trentino.” Journal of Borderlands Studies 35 (3): 467-485.

Engl, Alice. 2016. "Bridging Borders through Institution-Building: The EGTC as a Facilitator of Institutional Integration in Cross-Border Regions.” Regional \& Federal Studies 26 (2): 143-169.

Facchini, Marta. 2018. "Check Point Brennero, la via interrotta verso il Nord.” Scuola di giornalismo Walter Tobagi April 15, 2018. https://medium.com/@wtobagi/check-point-brennero-la-via-interrotta-verso-il-nord-cdf78dde36fd. (Accessed April 15, 2020).

Fondazione Alexander Langer, ASGI, and Antenne Migranti. 2017. "Lungo la rotta del Brennero."

Foppa, Brigitte. n.d. "La Proporzionale e la Petronilla.” Retrieved November 5, 2011. http://www.verdi.bz.it/.

Fuller, Mia. 2018. "Laying Claim: Mia Fuller on Italy's Internal and External Colonies." In A Moving Border: Alpine Cartographies of Climate Change, edited by Marco Ferrari, Elisa Pasqual, and Andrea Bagnato, 99-111. New York: Columbia University Press.

Grote, Georg. 2012. The South Tyrol Question, 1866-2010. Bern: Peter Lang.

Hansen, Lene. 2012. "Reconstructing Desecuritization: The Normative-Political in the Copenhagen School and Directions for How to Apply It." Review of International Studies 38 (3): 526-546.

Huttenbach, Henry R. 1996. "Editorial note: Divided Nations and the Politics of Borders." Nationalities Papers 24 (3): $369-370$. Huysmans, Jef. 2006. The Politics of Insecurity: Fear, Migration and Asylum in the EU. London: Routledge. 
Jaroszewicz, Marta, Kateryna Krakhmalova, and Jan Grzymski. 2020. "Securitisation /De-Securitisation of Internal Displacement in Ukraine as an Unintended Consequence of the State's Resilience Building." Paper presented at the ECPR Virtual General Conference, August 24-28.

Jutila, Matti. 2015. "Securitization, History, and Identity: Some Conceptual Clarifications and Examples from Politics of Finnish War History.” Nationalities Papers 43 (6): 927-943.

Kaplan, David H. 2000. "Conflict and Compromise among Borderland Identities in Northern Italy." Tijdschrift voor Economische en Sociale Geografie 91(1): 44-60.

Kind-Kovacs, Friederike. 2014. "Memories of Ethnic Cleansing and the Local Iron Curtain in the Czech-German Borderlands." Nationalities Papers 42 (2): 199-222.

Knoll, Sven. 2011. "Meilenstein in der Einwanderungspolitik: Landtag genehmigt gezielte Anwerbung von EU-Arbeitskräften." Retrieved September 17, 2011. http://www.suedtiroler-freiheit.com.

Kreide, Regina. 2019. “Crossing (Out) Borders: Human Rights and the Securitization of Roma Minorities.” In The Securitization of the Roma in Europe, edited by Huub van Baar, Ana Ivasiuc, and Regina Kreide, 45-66. Cham: Palgrave.

Lega. n.d. "Domenica Ottobre 21. Il Programma."

Oates-Indruchová, Libora, and Muriel Blaive. 2014. "Border Communities: Microstudies on Everyday Life, Politics and Memory in European Societies from 1945 to the Present." Nationalities Papers 42 (2): 195-198.

Obermair, Hannes. 2018. "A History-Blind South Tyrol? (Missing) Memory Cultures 1918-2018 as Failure of Critical Consciousness.” In 100 Jahre Erster Weltkrieg - Europa und europaregion/Centenario Grande Guerra - Europa ed Euregio, edited by Matthias Fink and Günther Rautz, 19-28. Bolzano: European Region Tyrol-South TyrolTrentino.

Olesker, Ronnie. 2014. "National Identity and Securitization in Israel." Ethnicities 14 (3): 371-391.

Pallaoro, Alessandro, and Micaela Colletti. 2013. “Nuove' minoranze in Alto Adige/Südtirol.” In Politiche Migratorie e Autonomie Territoriali, edited by Roberta Medda-Windischer and Andrea Carlà, 115-159. Bolzano: Eurac Research.

Pallaver, Günther, ed. 2013. Politika 13. Bozen: Edition Raetia.

Pallaver, Günther. 2008. "South Tyrol's Consociational Democracy: Between Political Claim and Social Reality.” In Tolerance through Law, edited by Jens Woelk, Francesco Palermo, and Joseph Marko, 303-327. Leiden: Martinus Nijhoff.

Pallaver, Günther. 2014. "South Tyrol's Changing Political System: From Dissociative on the road to Associative Conflict Resolution.” Nationalities Papers 42 (3): 376-398.

Pan, Christoph. 2016. "Minderheitenschutz und Wirtschaft." In Handbuch der europäischen Volksgruppen Band 1, 2nd ed., edited by Christoph Pan, Beate Sibylle Pfeil, and Paul Videsott, 343-383. Wien: Verlag Österreich.

Peterlini, Oskar. 1996. Autonomia e tutela delle minoranze nel Trentino Alto Adige. Bolzano: Ufficio di Presidenza del Consiglio regionale del Trentino Alto Adige.

Progetto Melting Pot Europa. 2017. "Lungo la rotta del Brennero: Rapporto di monitoraggio sulla situazione dei migranti al Brennero e Bolzano; Un lavoro congiunto tra Antenne Migranti e l'ASGI.” September 26, 2017. https://www.meltingpot.org/ Lungo-la-rotta-del-Brennero-rapporto-di-monitoraggio-sulla.html\#.XgCnSEF7mcw. (Accessed April 15, 2020.)

Provincia Autonoma di Bolzano and Eurac Research. 2017. Richiedenti asilo e rifugiati in Alto Adige.

Quadroni, Andrea, and Michele Luppi. 2017. "Morire di confine al Brennero." Open Migration July 27, 2017. https:// openmigration.org/analisi/morire-di-confine-al-brennero/. (Accessed April 15, 2020).

Rabini, Chiara. 2018. "Relazione sull'attività della Referente per i richiedenti asili e rifugiati: Periodo di rifermento novembre 2016 - marzo 2018.” Consiglio Comunale di Bolzano. Bolzano.

Reuber, Paul. 2012. Politische Geographie. Paderborn: Ferdinand Schöningh.

Salat, Levente. 2014. "The Chance of Ethnic Autonomy in Romania: Between Theory and Practice." In Autonomies in Europe: Solutions and Challenges, edited by Zoltán Kántor, 123-139. Budapest: L'Harmattan.

Saltarelli, Salvatore, and Monika Weissensteiner. 2015. "La rotta del Brennero." In Dossier Statistico immigrazione 2015, edited by IDOS, 121-124. Roma: IDOS.

Saltarelli, Salvatore, and Monika Weissensteiner. 2016. "La 'rotta del Brennero." In Dossier Statistico immigrazione 2016, edited by IDOS, 129-132. Roma: IDOS.

Saltarelli, Salvatore. 2017. "Nuovi sviluppi nel sistema di accoglienza in provincia di Bolzano.” Il Cristallo 1:46-54.

Scantamburlo, Matthias. 2016. "Partiti e autodeterminazione in südtirol/alto adige: Competizione etnica e strategie dei partiti tra autonomia e secessione." Nazioni e regioni 7:47-70.

SVP. 2016. SVP-Grundsatzprogramm. https://www.svp.eu/de/programm-931.html. (Accessed April 21, 2021.).

SVP. 2018. Stabil. Stark. Südtirol! https://www.svp.eu/smartedit/documents/content/sub/_published/suedtiroler-volksparteiwahlprogramm-2018_1.pdf. (Accessed April 21, 2021.)

Trédaniel, Marie, and Pak K. Lee. 2018. "Explaining the Chinese Framing of the 'Terrorist' Violence in Xinjiang: Insights from Securitization Theory." Nationalities Papers 46 (1): 177-195.

van Willigen, Niels. 2010. "From Nation-Building to Desecuritization in Bosnia and Herzegovina." Security and Human Rights 21 (2): $127-138$.

Weissensteiner, Monika. 2016. "Protezione e modelli di accoglienza: Il Sudtirolo tra dinamiche locali, europee e globali." Il Cristallo 1:39-46. 


\section{Andrea Carlà}

Williams, Kira, and Alison Mountz. 2018. "Between Enforcement and Precarity: Externalization and Migrant Deaths at Sea." International Migration 56 (5): 74-89.

Wisthaler, Verena. 2016. "South Tyrol: The Importance of Boundaries for Immigrant Integration." Journal of Ethnic and Migration Studies 42 (8): 1271-1289.

Wlasak, Petra. 2017. "Grenzen im Spannungsfeld von staatlichem Flüchtlingsmanagement, gesellschaftlichem Diskurs und migrantischer Selbstbestimmung." In Politika 2017, edited by Elisabeth Alber, Alice Engl, and Günther Pallaver, 53-63. Bozen: Edition Raetia.

Woelk, Jens, Francesco Palermo, and Joseph Marko. 2008. Tolerance through Law. Leiden: Martinus Nijhoff.

Wolff, Stefan. 2008. “Complex Power Sharing as Conflict Resolution: South Tyrol in Comparative Perspective.” In Tolerance through Law, edited by Jens Woelk, Francesco Palermo and Joseph Marko, 329-370. Leiden: Martinus Nijhoff.

Cite this article: Carlà, A. 2022. Securitizing Borders: The Case of South Tyrol. Nationalities Papers 50: 166-184, doi:10.1017/ nps.2021.14 